\title{
Membangun Identitas Anak Remaja Dalam Menghadapi Masalahnya Sendiri
}

\author{
Desi \\ STAK Terpadu PESAT \\ desipesat@gmail.com
}

\begin{abstract}
ABSTRAK
Youth are pioneers of change for the fucture of a nation. Adolescent development itself is a transitional period from childhood to physical maturity, adolescence lasts between the ages of 12-21 years for women while for men 13-22 years. In the developmental stages, adolescents experience difficulties, especially in building self-identity, such as difficulty accepting physical conditions, gaining emotional freedom, difficulty in socializing, difficulty finding self-models, difficulty knowing and accepting self-abilties, difficulty adolescents in strengthening self-control and difficulty leaving reactions and childhood adjustment. The purpose of this study is to determaine whether there is an impact on the role of parents in building adolescent identity, so that adolescentscan face their own problems. The results of literature research show that the role of parents greatly contributed to the formation of the identity of adolescents in building their identity. In addition, the contribution of children in knowing and understanding themselves is a major factor so that teenagers are able to face own problems.
\end{abstract}

Keywords: Building identity, Adolescents, The role of parents, Facing their own problems.

\begin{abstract}
ABSTRAK
Remaja merupakan pionir perubahan bagi masa depan suatu bangsa. Perkembangan remaja sendiri merupakan masa peralihan dari masa anak-anak sampai mencapai kematangan secara fisik, masa remaja berlangsung antara umur 12-21 tahun bagi wanita sedangkan bagi pria 13-22 tahun. Dalam perkembangan tahap pertahapnya remaja mengalami kesulitan-kesulitan terutama membangun identitas diri, seperti sulitnya menerima keadaan fisik, memperoleh kebebasan emosional, sulitnya bergaul, sulitnya menemukan model diri, sulitnya mengetahui dan menerima kemampuan diri, sulitnya remaja dalam memperkuat penguasan diri dan sulitnya meninggalkan reaksi dan penyesuaian masa kanakkanak. Tujuan dari penelitian ini untuk mengetahui ada tidaknya dampak dari peran orang tua dalam membangun identitas remaja, sehingga anak remaja dapat menghadapi masalahnya sendiri. Hasil penelitian kepustakaan menunjukan bahwa peran orang tua sangat berkontribusi besar bagi pembentukan identitas anak remaja dalam membangun identitasnya. Selain itu, kontribusi dari anak dalam mengetahui dan memahami dirinya, menjadi faktor yang utama sehingga dengan demikian anak remaja mampu menghadapi masalahannya sendiri.
\end{abstract}

Kata Kunci: Membangun identitas, Anak remaja, Peran orang tua, Menghadapi masalahnya sendiri. 
PENDAHULUAN

Remaja merupakan pionir perubahan bagi masa depan suatu bangsa. Masa remaja merupakan tahap kehidupan yang besifat peralihan dari kanak-kanak ke masa remaja, disamping itu masa remaja mudah dipengaruhi oleh hal-hal negatif seperti narkoba, merokok, dan sebagainya. Disisi lain remaja dipengaruhi oleh ketidakstabilan emosi sehingga mudah dipengaruhi oleh teman dan lebih mengutamakan kelompoknya diandingkan dengan mengutamakan keluarga. ${ }^{1}$ Emosi yang tidak stabil ini dapat mempengaruhi remaja dalam menghadapi masalahnya sendiri. Remaja kerap kali tidak mampu menghadapi masalahnya sendiri di karenakan munculnya tekanan dan tuntutan yang diterima oleh remaja itu sendiri baik dari lingkungan keluarga maupun lingkungan sekitar. Tekanan dan tuntutan ini yang menghambat remaja untuk membangun identitas dirinya. Membangun identitas diri anak remaja merupakan hal terpenting yang harus dihadapi oleh remaja itu sendiri maupun oleh orang tua.

\footnotetext{
${ }^{1}$ Putri Rosalia Ningrum, "Perceraian Orang Tua Dan Penyesuaian Diri Remaja Studi Pada Remaja Sekolah Menengah Atas/Kejuruan Di Kota Samarinda," Psikoborneo: Jurnal Ilmiah Psikologi 1, no. 1 (2013): 39-44, http://ejournals.unmul.ac.id/index.php/psikoneo/article/vi ew/3278.
}

Fenomena kesulitan-kesulitan remaja dalam membangun identitas biasanya sering terjadi di kalangan remaja yang mengalami peralihan dari masa anak-anak ke masa remaja. Kesulitankesulitan ini menjadi tekanan yang luar biasa bagi remaja yang baru beranjak remaja. Ada banyak permasalahan dan kesulitan yang terjadi di kalangan remaja terutama permasalahan dan kesulitan mengenai identitas dirinya. Kehidupan remaja khususnya remaja awal tidak lepas dari permasalahan karena perubahan secara fisik, kognitif dan sosial-emosional yang dapat mempengaruhi dirinya dalam mengontrol dan memandang masalah yang dihadapinya. $^{2}$

Menurut penulis dari penjelasan di atas bahwa masa remaja merupakan perkembangan remaja dari tahap ke tahap yang dapat mempengaruhi pola pikir, perilaku dan tindakan seorang remaja. Adapun tanda yang spesifik dalam kehidupan remaja yakni adanya perubahan-perubahan fisologis yang menyebabkan remaja tersebut mengalami kematangan seksual dan pubertas dimana pada masa ini anak remaja dipenuhi pelbagai aktivitas yang pada intinya

\footnotetext{
${ }^{2}$ Indrariyani Artha and - Supriyadi, "Hubungan Antara Kecerdasan Emosi Dan Self Efficacy Dalam Pemecahan Masalah Penyesuaian Diri Remaja Awal Ni Made Wahyu Indrariyani Artha Dan Supriyadi," Jurnal Psikologi Udayana 1, no. 1 (2013): 190-202.
} 
merupakan pencarian identitas diri remaja. Menurut mappire sendiri masa remaja itu berlangsung antara umur 12-21 tahun bagi wanita sedangkan bagi pria 13-22 tahun. Artinya bahwa masa remaja berakhir jika wanita maupun pria mencapai umur yang telah dikemukakan oleh mappire. Tahap ini akan terus berlanjut dan tentunya mengalami perubahan terutama perubahan secara fisik. Perubahan tersebut dalam bentuk dan ciri-ciri fisik yakni berkaitan erat dengan mulainya pubertas pada anak remaja. Remaja adalah usia yang tidak lagi merasa dibawah tingkat orang dewasa tetapi sama dengan tingkatan orang tua. Masa remaja sebagai periode penting, baik periode fisik mapun psikologi. Tanner juga menjelaskan bahwa sebagain besar anak remaja usia antara 12-16 tahun merupakan tahun kehidupan yang penuh kejadian sepanjang menyangkut pertumbuhan dan perkembangan remaja tersebut. Pertumbuhan dan perkembangan remaja menjadi sangat penting, terutama untuk membangun identias diri remaja. Pada masa remaja terdapat berbagai proses yang mencakup biologis dan psikologi anak remaja tersebut. $^{3}$

\footnotetext{
${ }^{3}$ Mohammad Zaini, "Pendidikan Remaja Dalam Perspektif Psikologi Pendidikan," EL-BANAT: Jurnal Pemikiran Dan Pendidikan Islam 8, no. 1 (2018): 99-117, http://ejournal.kopertais4.or.id/susi/index.php/elba nat/article/view/2983.
}

James Marcia dan waterman (dalam yusuf, 2000) mengatakan bahwa identitas diri merujuk kepada pengaturan dorongan-dorongan, kemampuan dan keyakinan ke dalam gambaran diri secara tetap yang meliputi kemampuan dalam memilih dan mengambil keputusan yang menyangkut pekerjaan, orientasi seksual dan filsafat hidup. ${ }^{4}$

\section{Erik Erikson}

(1902-1994)

berpendapat bahwa ada beberapa tahapan perkembangan kepribadian salah satunya tahapan identitas vs kebinggungan peran. Tahapan ini ditandai oleh adanya perubahan fisiologis yang dramatis yang berhubungan dengan maturasi seksual. Artinya bahwa pada tahapan ini anak remaja mulai memfokuskan diri pada penampilan dan citra tubuh. Dalam hal ini remaja juga mulai membentuk identitas diri dengan tujuan agar memiliki pandangan dan arahan mengenai diri dan menjawab pertanyaan mengenai dirinya. Pembentukan identitas ini sangat penting agar anak remaja dapat menentukan pilihan dan dapat memutuskan keputusan

\footnotetext{
${ }^{4}$ Beely Jovan Sumakul, "Peranan Komunikasi Keluarga Dalam Pembentukan Identitas Remaja Di Kelurahan Malalayang I Kecamatan Malalayang Kota Manado," ACTA DIURNA KOMUNIKASI 4, no. 4 (2015): 1-9, https://ejournal.unsrat.ac.id/index.php/actadiurnak omunikasi/article/view/8502/8077.
} 
yang tepat serta memecahkan masalahnya sendiri. $^{5}$

Dengan demikian menurut penulis, identitas anak remaja menjadi bagian yang sangat penting. Artinya bahwa membangun identitas anak remaja sejak dini menjadi tugas dan peran orang tua dalam mengasuh, membimbing, mendidik dan mengarahkan anak. Peran yang diemban oleh orang tua bukanlah perkara yang ringan dibutuhkan kesabaran, kepedulian, kasih sayang dan tentunya memiliki pengetahuan yang dapat membangun identitas diri anak sejak dini dengan memberikan kesempatan kepada anak dalam menyampaikan pendapatnya. Peran orang tua tidak hanya mengasuh dan memenuhi kebutuhan anak tetapi membangun identitas anak sejak dini, sehingga anak remaja dapat bertanggung jawab dengan masalah yang dihadapinya.

Dalam hal ini orang tua perlu mengetahui pertumbuhan dan perkembangan yang terjadi pada anak remaja. Orang tua merupakan kelompok yang utama dalam membangun identitas anak remaja. Orang tua perlu memahami dan mengerti tugas perkembangan yang terjadi dalam diri remaja. Remaja dapat memilih keyakinan hidup yang dipilihnya.

\footnotetext{
${ }^{5}$ Sri Ramdaniati, Enie Novieastari, Kusman Ibrahim, Deswani, Dasar-Dasar Keperawatan (Singapore: Elsevier Healthy Sciences, 2020). Hal. 95.
}

Keyakinan yang dipilihnya dapat membentuk identitas diri remaja tersebut. Dalam hal ini peran orang tua memang sangat penting, tetapi yang lebih penting jika remaja dapat mengetahui kesulitankesulitan yang dialami dalam membangun identitas diri dan perkembangan identitas remaja itu sendiri. Untuk menaggulangi kesulitan-kesulitan yang muncul dalam diri remaja peran orang tua menjadi hal yang sangat penting untuk pembentukan identitas anak remaja dan dalam membangun identitas dirinya, remaja perlu mengetahui kesulitan-kesulitan dalam membangun identitas drinya, sehingga memudahkan remaja tersebut dalam memahami, mengenali, menemukan dan menerima identitas dirinya.

Penelitian ini bertujuan untuk mendeskripsikan kondisi yang dapat membangun identitas anak remaja dalam menghadapi masalahnya sendiri dan perkembangan identitas diri remaja melalui peran orang tua, di mana orang tua perlu memahami dan mengerti tugas perkembangan yang terjadi dalam diri anak remaja. Dengan peran orang tua dan kesadaran dari remaja tersebut dalam mengenali identitasnya, maka remaja dapat bertanggung jawab terhadap masalahnya sendiri. 
Berdasarkan uraian yang telah disampaikan peneliti di atas, maka hipotesis yang diajukan adalah adanya kesulitan-kesulitan yang dialami oleh remaja dalam membangun identitasnya, sehingga dibutuhkan peran orang tua dalam membangun identitas remaja dalam menghadapi masalahnya sendiri.

\section{METODE PENELITIAN}

Metode penelitian yang digunakan adalah metode penelitian yang identik dengan kegiatan analisis teks atau wacana yang menyelidiki suatu peristiwa, baik berupa perbuatan atau tulisan yang diteliti untuk mendapatkan fakta-fakta yang tepat dalam menemukan asal- usul, sebab akibat dan penyebab dari masalah. ${ }^{6}$ Metode penelitian kepustakaan juga merupakan metode yang dalam proses penelitiannya sudah berlangsung pada saat pencatatan penelitian itu dilakukan. Penelitian ini dapat dilihat dari pengelompokan topik atau tema-tema kecil tertentu ke dalam judul-judul kartu catatan di halaman pertama yang disebut "headings", berdasarkan masalah yang dicatat, dan pengelompokan kartu catatan menurut bentuk isi seperti ekstrak kata demi kata,

\footnotetext{
${ }^{6}$ Amir Hamzah, Metode Penelitian Kepustakaan: Kajian Filosofis,Aplikasi, Proses, Dan Hasil Penelitian. (Malang: Literasi nusantara, 2020). Hal. 7
}

ringkasan, referensi, deskritif dan reflektif. ${ }^{7}$ Dalam hal ini penulis menggunakan metode kepustakaan dengan mencantumkan dari beberapa sumber buku dan jurnal yang berhubungan dengan masalah yang dirumuskan oleh penulis dengan mengelompokan topik dan tematema kecil serta mencatat berdasarkan masalah atau topik yang diangkat oleh penulis.

\section{PEMBAHASAN DAN HASIL}

\section{Membangun Identitas Anak Remaja}

Perkembangan remaja merupakan masa pubertas yang meliputi masa peralihan dari masa anak-anak sampai mencapai kematangan secara fisik, yakni umur 12-15 tahun. Remaja merupakan masa peralihan dari masa kanak-kanak menuju dewasa yakni umur 12-21 tahun. Menurut J. Piaget sendiri memandang bahwa "adolescentia" sebagai fase hidup dengan perubahan-perubahan penting pada fungsi inteligensi yang mencakup perkembangan aspek kognitif. Menurut ahli lain mengatakan bahwa masa remaja itu, merupakan masa timbulnya perasaan baru tentang identitas daripada masa adolescentia. Artinya bahwa dapat terbentuknya gaya hidup tertentu

\footnotetext{
${ }^{7}$ Mestika Zed, Metode Penelitian Kepustakaan (Jakarta: Yayasan Obor Indonesia, 2008). Hal. 72.
} 
sehubungan dengan penempatan dirinya yang dapat dikenal oleh lingkungannya walaupun mengalami perubahan pada dirinya yang dikemukakan oleh E.H. Erikson. ${ }^{8}$

A.Bandura juga berpendapat bahwa masa remaja menjadi masa pertentangan dan masa pemberontakan, hal ini terjadi karena terlalu menitikberatkan ungkapan-ungkapan yang dianggap bebas dan ringandari ketidakpatuhan, seperti model rambut yang digunting, gaya berpakaian, bacaan, film yang ditonton dan sering kali remaja digambarkan sebagai kelompok yang tidak bertanggung jawab, melawan, memberontak dan dinilai secara umum tidak berperilaku baik dan hanya sensasional. Sikap dan pandangan ini tidak dapat mendukung sifat-sifat lebih dewasa dalam masa peralihan remaja ini. ${ }^{9}$

Pada masa remaja pertumbuhan fisik dan psikologi remaja juga dapat mempengaruhi perkembangan kebutuhan yang diperlukan remaja seperti ingin dicintai dan mencintai, ingin mendapatkan pegalaman, termasuk kebutuhan akan identitas dan kebutuhan dibimbing, diarahkan, diberi motivasi oleh orang dewasa. Perlu kita ketahui bahwa salah

${ }^{8}$ Gunarsa d. singgih \& Yulia d. Gunarsa, Psikologi Perkembangan Anak \& Remaja (Jakarta: Libri PT BPK Gunung Mulia, 2011).Hal. 202.

${ }^{9}$ Ibid. Hal. 205. satu tahap kehidupan manusia itu melalui tahap masa remaja. Remaja merupakan tahap transisi yang pada umunya mengalami banyak tekanan dan perubahan-perubahan yang terjadi pada diri remaja. Pada tahap ini remaja membutuhkan dukungan, baik dukungan internal seperti memotivasi diri dan mendukung diri sendiri maupun ekternal yakni dukungan keluarga, orang tua atau teman sebaya bahkan lingkungan sekitarnya, sehingga menjadi remaja yang mampu menghadapi masalahnya sendiri. Menurut Hurlock (2003) mengatakan bahwa remaja merupakan masa yang bermasalah. Isu-isu yang menjadi masalah bagi remaja adalah citra tubuh, peran sosial dan perilaku sosial termasuk identitas remaja. Masalah yang terjadi cenderung sulit untuk diatasi oleh remaja, tanpa adanya bantuan dari orang lain (Menurut Dina Zakiyyatul Fuadah, Ratna Hidayati, and Aida Fitriyah dalam jurnalnya). ${ }^{10}$ Artinya bahwa masa remaja itu masa yang penuh dengan masalah, tidak ada remaja yang tidak bermasalah, baik pada perkembangan fisik maupun perkembangan pisikis remaja itu sendiri.

\footnotetext{
${ }^{10}$ Dina Zakiyyatul Fuadah, Ratna Hidayati, and Aida Fitriyah, "Intervensi Dukungan Kelompok Sebaya Terhadap Kemampuan Menyelesaikan Masalah Pada Remaja," Jurnal Ners dan Kebidanan (Journal of Ners and Midwifery) 6, no. 2 (2019): 120-125.
} 
Pandangan psikoanalisis sendiri mengatakan bahwa masa remaja kerap kali menyalahgunakan narkoba, yang dapat dipahami, bahwa remaja tersebut mengalami kecemasan, ketakutan dan kekhwatiran dalam diri karena tidak mampu menghadapi masalah dalam mencari identitas diri, sehingga tanpa disadari remaja menggunakan mekanisme pertahanan diri seperti mengkonsumsi narkoba, meroko, mengkonsumsi obat penenang dan sebagainya. ${ }^{11}$

Dalam tugas perkembangan remaja lebih difokuskan untuk mencapai kemampuan bersikap dan berperilaku secara dewasa. Adapun tugas-tugas perkembangan menurut Hurlock (1991) antara lain:

a) Remaja diharapkan mampu menerima keadaan fisiknya

b) Remaja dapat memahami dan mengerti peran seks usia dewasa

c) Remaja mampu mencapai kemandirian

d) Remaja mampu mengembangkan konsep dan keterampilan

e) Remaja mampu meninteralisasikan nilai-nilai orang dewasa dna orang tua

\footnotetext{
${ }^{11}$ Singgih D. Gunarsa, Dari Anak Sampai Usia Lanjut:Bunga Rampai Psikologi Anak (Jakarta, 2004). Hal. 218.
}

f) Remaja mampu bertanggung jawab dengan diri sendiri dan orang lain

g) Remaja sudah mampu mempersiapkan diri memasuki perkawinan dan mempersisapkan berbagai tanggung jawab keluarga.

Dalam tugas perkembangan di atas, akan tercapai jika anak remaja menyadari dan mengetahui siapa identitas diri yang sebenarnya. ${ }^{12}$ Setiap individu tumbuh dan berkembang melalui tahaptahap perkembangan. Setiap perkembangan yang dilalui oleh remaja tentunya memiliki serangkaian tugas yang harus dilalui dengan baik oleh individu. Menurut Havighurst (Hurlock, 1990) mengatakan bahwa setiap remaja harus melalui perkembangan dengan baik, perkembangan tersebut antara lain:

a) Mencapai hubungan baru yang lebih matang dengan teman sebaya

b) Mencapai peran sosial pria dan wanita

c) Menerima keadaan fisiknya dengan menggunakan secara efektif

d) Mencari kemandirian emosional dari orang tua dan masih banyak tugas perkembangan yang lainnya

\footnotetext{
${ }^{12}$ Mohammad ali \& mohammad Asrori., Psikologi Remaja:Perkembangan Peserta Didik (Jakarta: PT Bumi Aksara, 2004). Hal. 10
} 
yang harus dilalui oleh seorang remaja dalam membangun identitas diri. ${ }^{13}$

Perlu diketahui bahwa masa remaja adalah masa peralihan dari masa kanak-kanak menuju dewasa, sehingga terjadi perubahan dan minat yang diinginkan oleh remaja. Masa ini merupakan tahapan terpenting dalam kehidupan remaja yang dimulai pada masa puber dan berakhir pada usia 18 atau 21 tahun. Masa remaja ditandai dengan adanya identitas versus kebinggungan identitas yang merupakan tugas utama pada diri remaja dalam menghadapi identitas itu sendiri. ${ }^{14}$ Hal ini dilakukan oleh remaja karena mereka ingin mendapatkan identitas diri mereka sendiri tanpa bantuan dari orang lain termasuk orang tua.

Masa remaja merupakan rangkaian perubahan yang dialami oleh remaja itu sendiri. Masa ini masa yang dapat dikatakan sebagai masa yang umum dan normal yang meliputi berbagai rangkaian konflik. Masa ini sebagai masa krisis identias. Hal yang perlu kita ketahui ada

\footnotetext{
13 Ibid. Hal. 164-166.

${ }^{14}$ Sugeng Sejati, "Implikasi Egosentris Dan Spiritual Remaja Dalam Mencapai Perkembangan Identitas Diri," Jurnal Ilmiah Syi'ar 19, no. 1 (2019): 103-126,

file://C:/Users/ASUS/Downloads/2269-5470-1SM (7).pdf.
}

dua proses pembentukan identitas remaja yang berada dalam masa krisis meliputi:

a) Usaha untuk menolak dan mengambil teladan dan tokoh identitfikasi

b) Mencoba melakukan peran sebagai pria maupun wanita.

Ada juga beberapa faktor penting dalam tugas perkembangan membangun identitas yang meliputi:

a) Kepercayaan diri yang dibentuk dari awal yang diperoleh dari orang tua

b) Memiliki sikap mandiri yang sudah dibina sejak dini

c) Keadaan keluarga yang dapat menunjang identitas diri seorang remaja

d) Kemampuan remaja dalam meningkatkan taraf kemampuan intelek dalam diri remaja. ${ }^{15}$

Berkaitan dengan hal diatas yang telah dikemukakan oleh beberapa ahli, maka masa ini menjadi masa yang sulit dalam membangun identitas remaja. Untuk membangun identitas, remaja mengalami kesulitan-kesulitan yang cenderung sulit untuk diatasi oleh remaja, tanpa adanya bantuan dari orang lain,

\footnotetext{
${ }^{15}$ Yulia Singgih D. Gunarsa \& Singgih D. Gunarsa, Psikologi Remaja (Jakarta: Libri PT BPK Gunung Mulia, 2012). Hal. 86-92.
} 
maka akan mempersulit remaja tersebut membangun identitas dirinya.

\section{Kesulitan-Kesulitan Remaja Dalam}

\section{Membangun Identitas Diri}

Tugas perkembangan pada umumnya dapat dilaksanakan dengan baik jika tidak ada halangan, baik dari lingkungan maupun dari remaja tersebut. Adapun kesulitan yang dihadapi remaja dalam tugas perkembangannya antara lain:

1) Sulitnya menerima keadaan fisik Keadaan fisik menjadi masalah bagi remaja karena adanya perbedaan cara pandang antara harapan remaja dengan harapan lingkungan, sehingga menimbulkan masalah bagi remaja tersebut. Kurangnya penerimaan diri pada remaja menjadi masalah yang utama di kalangan remaja. Sebagian remaja merasa bahwa keadaan fisik itu penting untuk menunjang penampilan. Hal inilah yang mengakibatkan anak sulit membangun identitas dirinya karena melihat dari sisi fisiknya.

2) Kurangnya memperoleh kebebasan emosional

Dalam mengambil keputusan remaja perlu merenggangkan ikatan emosional dengan orang tua supaya dapat melatih sendiri dalam mengambil keputusan.

3) Sulitnya remaja dalam bergaul Remaja perlu belajar bergaul dengan lingkungan di mana ia tinggal. Belajar bergaul bisa saja dengan teman sebaya atau lawan jenis. Dalam bergaul kerap kali remaja mengalami pengaruh, baik pengaruh positif maupun negatif. Pengaruh positive dan pengaruh negatif akan menentukan identitas diri seorang remaja dalam menghadapi masalahnya sendiri.

4) Menemukan model diri Menurut E.H.Erikson mengatakan bahwa pada masa ini, remaja harus menemukan identitas diri. Remaja sering kali mempertanyakan siapa dirinya. Artinya bahwa membangun identitas diri remaja perlu dibangun atas dasar remaja dalam menemukan jati dirinya sendiri bukan pada orang lain dengan mencari dan menemukan identitas diri.

5) Mengetahui dan menerima kemampuan diri

Pada masa ini remaja dapat menunjukan minat terhadap peristiwa yang tidak kongkrit. Masa ini juga remaja mampu berfikir abstrak tentang diri dan kemampuannya. Dengan remaja 
mengetahui dan menerima kemampuan diri, maka remaja perlu mereflekesikan diri.

6) Sulitnya remaja dalam memperkuat penguasan diri

Remaja mudah terpengaruh dengan lingkungan, baik lingkungan dalam maupun lingkungan luar.

7) Sulitnya meninggalkan reaksi dan penyesuaian masa kanak-kanak

Pada masa ini remaja diharapkan mampu berpikir dewasa dalam menyikapi masalahnya sendiri dan mampu menyesuaikan diri dengan situasi dan kondisi yang ada di lingkungan keluarga dan lingkungan sekitar, sehingga dalam membangun identias dirinya, remaja dapat menghadapi masalahnya sendiri. ${ }^{16}$

\section{Peran Orang tua Membangun Identitas}

\section{Anak Remaja Dalam Menghadapi}

\section{Masalahnya Sendiri}

Menjadi orang tua adalah tugas yang mulia dan suatu kehormatan sekaligus tantangan paling menakutkan ketika mengambil peran untuk mendidik, mengasuh, membimbing dan mengarahkan anak kepada hidup yang

\footnotetext{
${ }^{16}$ Ibid. Hal. 207-216
}

lebih baik. setiap orang tua tentunya memiliki kesulitan-kesulitan dalam menghadapi anak terutama anak remaja yang akil balik, namun tidak semua orangtua menghadapi kesulitan karena tidak semua anak yang sedang akil balik berubah menjadi remaja yang sukar diatur, ada juga remaja yang mudah diarahkan, dibimbing dan dibina serta didik ke arah yang lebih baik. Pada masa ini anak remaja lebih mudah terpengaruh dengan berbagai isu-isu dan banyak media sosial yang mempengaruhi remaja dalam membangun identitas dirinya. Tampil beda, bertingkah laku beda, berfikir beda di mana hal ini menjadi bagian dari pengaruh yang membombardir remaja dalam membangun identitasnya. ${ }^{17}$

Remaja tidak dapat melakukan hal yang lebih jika orangtua tidak mendukung, membimbing, mendampingi dan mengarahkan anak kepada identitas diri. Pada masa remaja ini, remaja berharap dari orang tua supaya mereka mendapatkan tempat yang nyaman untuk membangun identitas diri. Pada kenyataanya tidaklah demikian sebagian besar remaja merasa tidak nyaman ketika orang tua yang menetapkan standar dan batasan-batasan yang dianggap oleh

\footnotetext{
${ }^{17}$ Steve Chalke, Awas Anak Anda Sudah Remaja:Bagi Orangtua Untuk Memahami Perilaku Dan Sikap Remaja. (Yogjakarta: Andi, 2007). Hal. 16.
} 
remaja tidak perlu orang tua lakukan. Sebenarnya remaja membutuhkan orang tua yang mendukung dan membutuhkan orang tua yang tanggap dengan permasalahan mereka. Ketika orang tua menetapkan standar dan batasan-batasan sebaiknya disertai dengan pujian jika anak melakukan hal yang tepat. Pada dasarnya orang tua menginginkan hal yang terbaik bagi anak remajanya agar tumbuh menjadi individu yang dewasa secara sosial namun kebanyakan orang tua merasa sangat frustasi dengan berperan sebagai orang tua. $^{18}$

Hubungan remaja dengan orang tua memiliki peran yang sangat penting dalam membangun identitas anak remaja. Hubungan yang solid dan positif tentunya akan berdampak baik bagi pembentukan identitas diri anak remaja. Keterlibatan orang tua secara khusus pembentukan identitas anak, maka secara tidak langsung orang tua sudah mendukung, memantau remaja baik di lingkungan sekitar maupun sekolah bahkan ketika anak tidak bersama dengan orang tua, anak remaja dapat bertanggung jawab atas hidupnya sendiri. ${ }^{19}$ Membangun identitas remaja bukanlah hal yang mudah apalagi pada anak remaja yang mengalami perubahan

\footnotetext{
${ }^{18}$ John w. Santrock, Remaja (Jakarta, 2007). Hal. 14.

${ }^{19}$ Alo Liliweri, Prasangka, Konflik, Dan Komunikasi Antar Budaya (Jakarta: Kencana, 2018). Hal. 136.
}

dratis dari masa kanak-kanak menuju masa remaja. Untuk itulah peran orang tua disini sangat diperlukan guna membangun identitas remaja, sehingga remaja dapat menghadapi masalahnya sendiri meskipun ada banyak masalah-masalah yang akan dialami oleh remaja itu sendiri.

Adapun peran orang tua dalam membangun identitas remaja sebagai berikut:

1) Orang tua dapat memberikan kasih sayang kepada anak dengan cukup

2) Memberikan pendidikan agama kepada anak remaja sejak dini

3) Menanamkan nilai-nilai dan moral yang baik kepada anak remaja sejak dini

4) Orangtua dapat menjadi roll model atau teladan bagi anak remaja baik dalam berperilaku, berkata dan bertindak.

5) Orang tua memberikan dukungan, motivasi dan arahan yang tepat untuk anak remaja dalam membangun identitas diri. Dukungan yang diberikan sangat berkontribusi besar bagi anak remaja yang mengalami peralihan dari anak-anak ke masa remaja. Kontribusi tersebut dapat membangun identitas anak remaja dengan baik. 
6) Sebaiknya ayah dan ibu dapat menerapkan pola asuh yang sama tidak ada perbedaan antara pola asuh ayah maupun ibu dari anak tersebut. Dengan adanya pola asuh yang sama dari orang tua, maka anak remaja tidak merasa dirinya dibeda-bedakan oleh orang tuanya.

7) Orang tua sebaiknya memberikan kesempatan kepada anak untuk mengemukakan pendapatnya mengenai keputusan-keputusan yang diambil secara bersama, sehingga anak remaja tidak merasa terabaikan dan dengan demikian anak remaja dapat mengambil keputusan-keputusan yang tepat, baik untuk dirinya maupun orang lain.

8) Orang tua juga perlu membatasi media sosial kepada anak remaja, di mana perkembangan teknologi semakin meningkat sehingga tanpa disadari anak dapap terpengaruh.

9) Orang tua menjadi sahabat untuk anak, agar anak remaja dapat terbuka dengan orang tua.

\section{KESIMPULAN}

Berdasarkan hasil penelitian kepustakaan, maka dapat disimpulkan bahwa perkembangan remaja sendiri merupakan masa peralihan dari masa anak-anak sampai mencapai kematangan secara fisik, masa remaja berlangsung antara umur 12-21 tahun bagi wanita sedangkan bagi pria 13-22 tahun. Dalam perkembangan tahap pertahapnya remaja mengalami kesulitan-kesulitan terutama membangun identitas diri, seperti sulitnya menerima keadaan fisik, memperoleh kebebasan emosional, sulitnya bergaul, sulitnya menemukan model diri, sulitnya mengetahui dan menerima kemampuan diri, sulitnya remaja dalam memperkuat penguasan diri dan sulitnya meninggalkan reaksi dan penyesuaian masa kanakkanak. Dalam hal ini peran orang tua memiliki dampak yang sangat besar bagi pembentukan identitas anak remaja dalam membangun identitasnya, sehingga dengan adanya peran orang tua dalam membangun identitas anak remaja dan kontribusi dari remaja dalam mengetahui dan memahami dirinya, maka anak remaja mampu menghadapi masalahannya sendiri.

\section{DAFTAR PUSTAKA}

Artha, Indrariyani, and - Supriyadi. "Hubungan Antara Kecerdasan Emosi Dan Self Efficacy Dalam Pemecahan Masalah Penyesuaian Diri Remaja Awal Ni Made Wahyu Indrariyani Artha Dan 
Supriyadi." Jurnal Psikologi Udayana 1, no. 1 (2013): 190-202.

Asrori, Mohammad ali \& mohammad.Psikologi

Remaja:Perkembangan Peserta Didik.

Jakarta: PT Bumi Aksara, 2004.

Chalke, Steve. Awas Anak Anda Sudah Remaja:Bagi Orangtua Untuk Memahami Perilaku Dan Sikap Remaja. Yogjakarta: Andi, 2007.

Enie novieastari, kusman Ibrahim, deswani, sri ramdaniati. Dasar-Dasar Keperawatan. Singapore: Elsevier healthy sciences, 2020.

Fuadah, Dina Zakiyyatul, Ratna Hidayati, and Aida Fitriyah. "Intervensi Dukungan Kelompok Sebaya Terhadap Kemampuan Menyelesaikan Masalah Pada Remaja." Jurnal Ners dan Kebidanan (Journal of Ners and Midwifery) 6, no. 2 (2019): 120-125.

Gunarsa, Yulia Singgih D. Gunarsa \& Singgih D. Psikologi Remaja. Jakarta: Libri pt bpk gunung mulia, 2012.

Gunarsa, Gunarsa d. singgih \& Yulia d. Psikologi Perkembangan Anak \& Remaja. Jakarta: Libri PT BPK Gunung Mulia, 2011.

Gunarsa, Singgih D. Dari Anak Sampai Usia Lanjut:Bunga Rampai
Psikologi Anak. Jakarta, 2004.

Hamzah, Amir. Metode Penelitian Kepustakaan: Kajian Filosofis,Aplikasi, Proses, Dan Hasil Penelitian. Malang: Literasi nusantara, 2020.

Liliweri, Alo. Prasangka, Konflik, Dan Komunikasi Antar Budaya. Jakarta: Kencana, 2018.

Ningrum, Putri Rosalia. "Perceraian Orang Tua Dan Penyesuaian Diri Remaja Studi Pada Remaja Sekolah Menengah Atas/Kejuruan Di Kota Samarinda." Psikoborneo: Jurnal Ilmiah Psikologi 1, no. 1 (2013): 39-44. http://ejournals.unmul.ac.id/index.php/psikoneo/a rticle/view/3278.

Santrock, John w. Remaja. Jakarta, 2007.

Sejati,Sugeng.“'Implikasi

Egosentris Dan Spiritual Remaja Dalam Mencapai Perkembangan Identitas Diri." Jurnal Ilmiah Syi'ar 19, no. 1 (2019): 103-126.

file://C:/Users/ASUS/Downloads/2269-

5470-1-SM (7).pdf.

Sumakul, Beely Jovan. "Peranan Komunikasi Keluarga Dalam Pembentukan Identitas Remaja Di Kelurahan Malalayang I Kecamatan Malalayang Kota Manado." ACTA DIURNA KOMUNIKASI 4, no. 4 (2015): 
$1-9$.

https://ejournal.unsrat.ac.id/index.php/acta

diurnakomunikasi/article/view/8502/8077.

Zaini, Mohammad. "Pendidikan

Remaja Dalam Perspektif Psikologi

Pendidikan."EL-BANAT:Jurnal Pemikiran

Dan Pendidikan Islam 8, no. 1 (2018):99-

117.

http://ejournal.kopertais4.or.id/susi/index.

php/elbanat/article/view/2983.

Zed, Mestika. Metode Penelitian

Kepustakaan. Jakarta: Yyayasan Obor

Indonesia, 2008. 